\title{
Analysis of 16S ribosomal RNA gene segments for the diagnosis of Gram negative pathogenic bacteria isolated from urinary tract infections
}

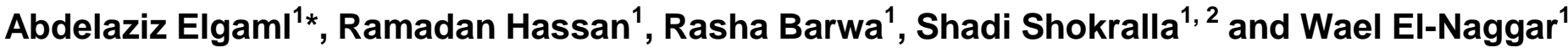 \\ ${ }^{1}$ Microbiology and Immunology Department, Faculty of Pharmacy, Mansoura University, Egypt. \\ ${ }^{2}$ Biodiversity Institute of Ontario, University of Guelph, Canada.
}

Accepted 3 June, 2013

\begin{abstract}
Bacterial 16S ribosomal RNA (rRNA) genes contain nine "hyper-variable regions" (V1-V9) that demonstrate considerable sequence diversity among different bacteria. Species-specific sequences within a given hyper-variable region constitute useful targets for diagnostic assays and other scientific investigations. No single region can differentiate among all bacteria; therefore, systematic studies that compare the relative advantage of each region for specific diagnostic goals are needed. We characterized V6 and V1 to V6 regions of 16S-rRNA gene in 20 Pseudomonas, 15 Escherichia and 15 Klebsiella species including common urinary tract pathogens using different primer sets specifically designed to amplify different regions of our marker. We determined that the 167 nucleotides-long V6 region is not suitable for distinguishing all bacterial strains to the genus and species level and could not distinguish among all bacterial species especially Klebsiella strains. The 1073 nucleotides-long V1 to V6 region is more accurate than identification using sequence analysis of V 6 region only and could identify all strains of unknown species Id. We also focused on how much sequencing information is needed for blind identification of bacterial pathogens. In conclusion, the DNA sequencing based method provides a valuable tool for cheap and accurate diagnosis of Gram-negative bacteria in urinary tract infections which can be applicable in other infections and in the diagnosis of other pathogenic bacteria.
\end{abstract}

Key words: Gram negative bacteria, urinary tract infections, $16 S-r R N A$ gene, sequencing.

\section{INTRODUCTION}

Accurate identification of bacterial isolates is an essential task of the clinical microbiology laboratory (Tang et al., 1998). In clinical laboratories the present means of identification of bacteria rely on phenotypic tests. Traditional phenotypic identification is difficult and time-consuming. In addition, when phenotypic methods are used to identify bacteria, interpretation of test results involves substantial subjective judgment (Bosshard et al., 2004). Phenotypic tests are characterized by potential inherent problems; example, (i) not all strains within a given species may exhibit a common characteristic (Beighton et al., 1991), (ii) the same strain may give different results upon repeated testing (Tardif et al., 1989), (iii) the corresponding database does not enclose newly or not yet described species, and (iv) the test result relies on individual interpretation and expertise. Moreover, small alterations in the execution of an assay may give false test results. Consequently, identification based on phenotypic tests does not always allow an unequivocal identification (Poyart et al., 1998). 
In the late of 1900 s, genotypic identification is emerging as an alternative or complement to established phenotypic methods. Typically, genotypic identification of bacteria involves the use of conserved sequences within phylogenetically informative genetic targets, such as the small-subunit 16S-rRNA gene (Wilson et al., 1990; Woese et al., 1990; Kirschner et al., 1993; Maurin et al., 1994).

Sequence analysis of the 16S ribosomal RNA (rRNA) gene has been widely used to identify bacterial species (Patel, 2001) and for diagnosing microbial infections (Trotha et al., 2001; Clarridge III, 2004). Ribosomal RNA molecules comprise several functionally different regions. Some of these are characterized by highly conserved sequences, that is, sequences that can be found among a wide range of bacteria. Other regions show highly variable sequences, that is, nucleic acid sequences that are specific for a species or a genus.

Thus, the 16S-rRNA sequence of a species is a genotypic feature which allows the identification of microbes at the genus or the species level (Boettger, 1996). In addition, molecular identification offers the possibility of recognizing yet un-described taxa, because ribosomal DNA similarity reflects phylogenetic relationships (Woese and Fox, 1977) and allowing independence from growth conditions (Clarridge III, 2004).

Bacterial 16S-rRNA genes generally contain nine "hyper-variable regions" (V1-V9) that demonstrates considerable sequence diversity among different bacterial species and can be used for species identification (Van de Peer et al., 1996). Species-specific sequences within a given hyper-variable region constitute useful targets for diagnostic assays and other scientific investigations. These nine hyper-variable regions are flanked by conserved stretches in most bacteria, enabling PCR amplification of target sequences using universal primers (Baker et al., 2003; Munson et al., 2004).

Identification of bacteria based on the sequences of their 16S-rRNA gene process carried out by extracting genomic DNA from bacteria is amplified and then sequenced. Sequence analysis software compares genes analyzed from unknown bacteria to a proprietary 16S-rRNA sequence library. The process has been done by using broad-range PCR primers (universal primers) to recognize conserved sequences in a variety of bacteria, while amplifying highly variable regions between the primer binding sites. The amplified segment is sequenced and compared with known databases to identify a close relative (Tang et al., 1998).

Unfortunately, 16S-rRNA hyper-variable regions exhibit different degrees of sequence diversity, and no single hyper-variable region is able to distinguish among all bacteria. In the present study we conducted a comparative evaluation of the bacterial identification which is based on sequence analysis of $16 \mathrm{~S}$ Ribosomal RNA gene segments using different Gram negative bacterial clinical isolates from urine specimens collected from Mansoura University Hospitals, Dakahlia governorate, Egypt.

\section{MATERIALS AND METHODS}

\section{Clinical isolates}

Twenty five isolates of Pseudomonas, twenty five isolates of Escherichia and twenty five isolates of Klebsiella were isolated and identified from Mansoura University Hospitals, Dakahlia governorate, Egypt. All the bacterial isolates were obtained from urine clinical specimens. The specimens were processed immediately using standard procedures and were identified according to the study of Barrow and Feltham (1993) and Collee et al. (1996).

\section{Phenotypic characterization of tested isolates}

\section{Pseudomonas isolates}

The samples were inoculated on cetrimide agar and nutrient agar plates. The overnight formed colonies at $37^{\circ} \mathrm{C}$ were examined and identified. The isolates were tested for their negative Gram-stain, colonial morphology, pigment production according to the study of Govan (1996), gelatin liquefaction, oxidase test and oxidation of sugars according to the study of Collee et al. (1996).

\section{Escherichia isolates}

The samples were inoculated on plates of nutrient agar and MacConkey's agar and incubated aerobically at $37^{\circ} \mathrm{C}$ for $24-48 \mathrm{~h}$. The isolates were tested for their negative Gram stain, oxidase test, fermentation of lactose on Macconkey's agar, methyl red test, Voges Proskauer's reaction, indole production and citrate utilization. All tests were performed according to the study of Barrow and Feltham (1993).

\section{Klebsiella isolates}

The samples were inoculated on plates of nutrient agar, blood agar and MacConkey's agar and incubated at $37^{\circ} \mathrm{C}$ for $24-48 \mathrm{~h}$. The isolated colonies were tested for their colonial morphology and negative Gram stain. Oxidase test, citrate utilization, methyl red test, Voges-Proskauer test, indole test, sugar fermentation and urease test were performed according to the study of Collee et al. (1996).

\section{Molecular experimental design}

\section{Genomic DNA extraction}

The genomic DNA of 50 isolates (20 Pseudomonas, 15 Escherichia and 15 Klebsiella isolates) were prepared using QIA amp® DNA mini Kit Cat. No. 51304 supplied by Qiagen Inc. according to the manufacturer instructions for bacteria 2003. DNA was eluted by adding $50 \mu \mathrm{l}$ Qiagen EB buffer (10 mM Tris-Hcl, $\mathrm{pH}$ 8.5) and visualized by electrophoresis on horizontal gels containing $1 \%$ agarose and Invitrogen $1 \mathrm{~kb}$ ladder.

\section{Primer design}

The primers used in this study were specifically designed before in Biodiversity Institute of Ontario, University of Guelph, Canada. Bact. 16S V6 Fw and Bact. 16S V6 Rv primer set to amplify the V6 region of $16 S-r R N A$ gene of the bacterial isolates with a size of $167 \mathrm{bp}$ and Bact. 16S V1 Fw and Bact. 16S V6 Rv primer set to amplify from V1 
Table 1. Specific amplification primer sets for the $\mathrm{V} 6$ and $\mathrm{V} 1$ to $\mathrm{V} 6$ regions of $16 \mathrm{~S}-\mathrm{rRNA}$ gene (Sundquist et al., 2007).

\begin{tabular}{lcc}
\hline Gene name & Type & Sequence \\
\hline V6 region of & $\mathrm{Fw}$ & $5^{\prime} \ldots$ AAACTCAAATGAATTGACGG \\
16S-rRNA & $\mathrm{Rv}$ & $5^{\prime} \ldots$ ACGAGCTGACGACATCCATG \\
& & \\
V1 to V6 region of & $\mathrm{Fw}$ & $5^{\prime} \ldots$ AGAGTTTGATCATGGCTCAG \\
16S-rRNA & $\mathrm{Rv}$ & $5^{\circ} \ldots$ ACGAGCTGACGACAGCCATG \\
\hline
\end{tabular}

Fw: Forward primer, Rv: Reverse primer.

to $\mathrm{V} 6$ region of $16 S-r R N A$ gene of the bacterial isolates with a size of 1073 bp (Table 1) (Sundquist et al., 2007).

\section{PCR}

The PCR reaction mixture was composed of $12.5 \mu \mathrm{l}$ GEN-Master Mix (2x) (dNTPs, MgCl2 and polymerase), $1 \mu$ l of forward primer (10 $\mu \mathrm{M}), 1 \mu \mathrm{l}$ of reverse primer $(10 \mu \mathrm{M}), 5 \mu \mathrm{l}$ of the isolated DNA template and $5.5 \mu \mathrm{l}$ of nuclease free water were added for a total of $25 \mu \mathrm{l}$ per reaction. We performed PCR in a Mastercycler epgradient $\mathrm{S}$ thermalcycler (Eppendorf, Mississauga, ON, Canada) including a negative control reaction with each primer set employing Platinum Taq polymerase supplied by Invitrogen (Burlington, ON, Canada). The amplification cycling was performed as follows, primary initial activation step at $95^{\circ} \mathrm{C}$ for $5 \mathrm{~min}$, followed by 40 cycles of $94^{\circ} \mathrm{C}$ for 15 $\mathrm{s}, 46^{\circ} \mathrm{C}$ for $30 \mathrm{~s}$, and $72^{\circ} \mathrm{C}$ for $30 \mathrm{~s}$, followed by final extension of $72^{\circ} \mathrm{C}$ for $5 \mathrm{~min}$. The generated amplicons were visualized on $1.5 \%$ agarose gel electrophoresis stained with ethidium bromide and illuminated under UV transilluminator. Sequences were obtained using $\mathrm{ABI} 3730 \mathrm{XL}$ Big dye terminator Sanger sequencer (Applied Biosystems, Foster City, CA) (Sanger et al., 1977) and edited by the Codon-code aligner software, version 3.0.3.

\section{Sequence analysis and neighbor-joining tree construction}

Sequence analysis software compares genes analyzed from unknown bacteria to a proprietary $16 S-r R N A$ sequence library. The amplified regions of $16 S-r R N A$ gene of tested bacterial isolates were compared with known databases to identify a close relative. The amplified segments' sequences were compared online with standard $16 S-r R N A$ sequences of bacteria in the gene bank at website (http://www.ncbi.nlm.nih.gov/) using nucleotide BLAST (Basic Local Alignment Search tool).

After the accurate identification of each tested isolate to the species level, alignment and comparison of each V1 to V6 region of $16 S-r R N A$ gene sequences among each group of tested bacterial isolates with each other were performed and genetic diversity trees were constructed using megablast aligner software version 4.1 at website (http://www.megasoftware.net).

\section{RESULTS AND DISCUSSION}

\section{Phenotypic identification of bacterial isolates (Biochemical identification)}

By using biochemical identification methods, all the 75 clinical isolates were identified to the genus level as, 25 isolates of Pseudomonas, 25 isolates of Escherichia and 25 isolates of Klebsiella species.

\section{PCR amplification of $\mathrm{V} 6$ region and $\mathrm{V} 1$ to $\mathrm{V} 6$ region of 16S-rRNA gene}

The V6 and V1 to V6 regions of 16S-rRNA gene were amplified from genomic DNA of 20 isolates of Pseudomonas, 15 isolates of Escherichia and 15 isolates of Klebsiella. The generated amplicons were visualized with a size of 167 and 1073 base pair respectively as illustrated in Figure 1.

\section{Sanger sequences FASTA files and sequence analysis of tested isolates}

Nucleotide sequencing and data analysis of $\mathrm{V} 6$ and $\mathrm{V} 1$ to V6 regions of $16 S$-rRNA gene were carried out for the amplified PCR products. The obtained sequences were converted to Fasta file format and were compared online with standard 16S-rRNA sequences of bacteria in the gene bank using nucleotide BLAST to identify close relative.

The identification using sequence analysis of $\mathrm{V} 6$ region of $16 S$-rRNA gene could not identify all isolates to the species level. On the other hand, the identification using sequence analysis of $\mathrm{V} 1$ to $\mathrm{V} 6$ region of $16 \mathrm{~S}$-rRNA gene was more accurate than identification using sequence analysis of $\mathrm{V} 6$ region of $16 S$-rRNA gene and could identify all isolates of unknown species Id. This in accordance with the study of Kim et al. (2011), who showed that, by using longer reads spanning several hyper-variable regions gives accurate identification of bacteria and can produce results comparable with those obtained using full-length $16 S-r R N A$ reads.

\section{Pseudomonas}

Regarding the 20 Pseudomonas tested isolates; they could be classified into three groups, 15 isolates of $P$ s. aeruginosa, 2 isolates of Ps. putida and 3 isolates of Pseudomonas without species Id.

The sequencing of $\mathrm{V} 1$ to $\mathrm{V} 6$ region of $16 S-r R N A$ gene could discover the species Id of the three Pseudomonas isolates identified without species Id using sequencing of V6 region of $16 S-r R N A$ gene and the net identification 
A
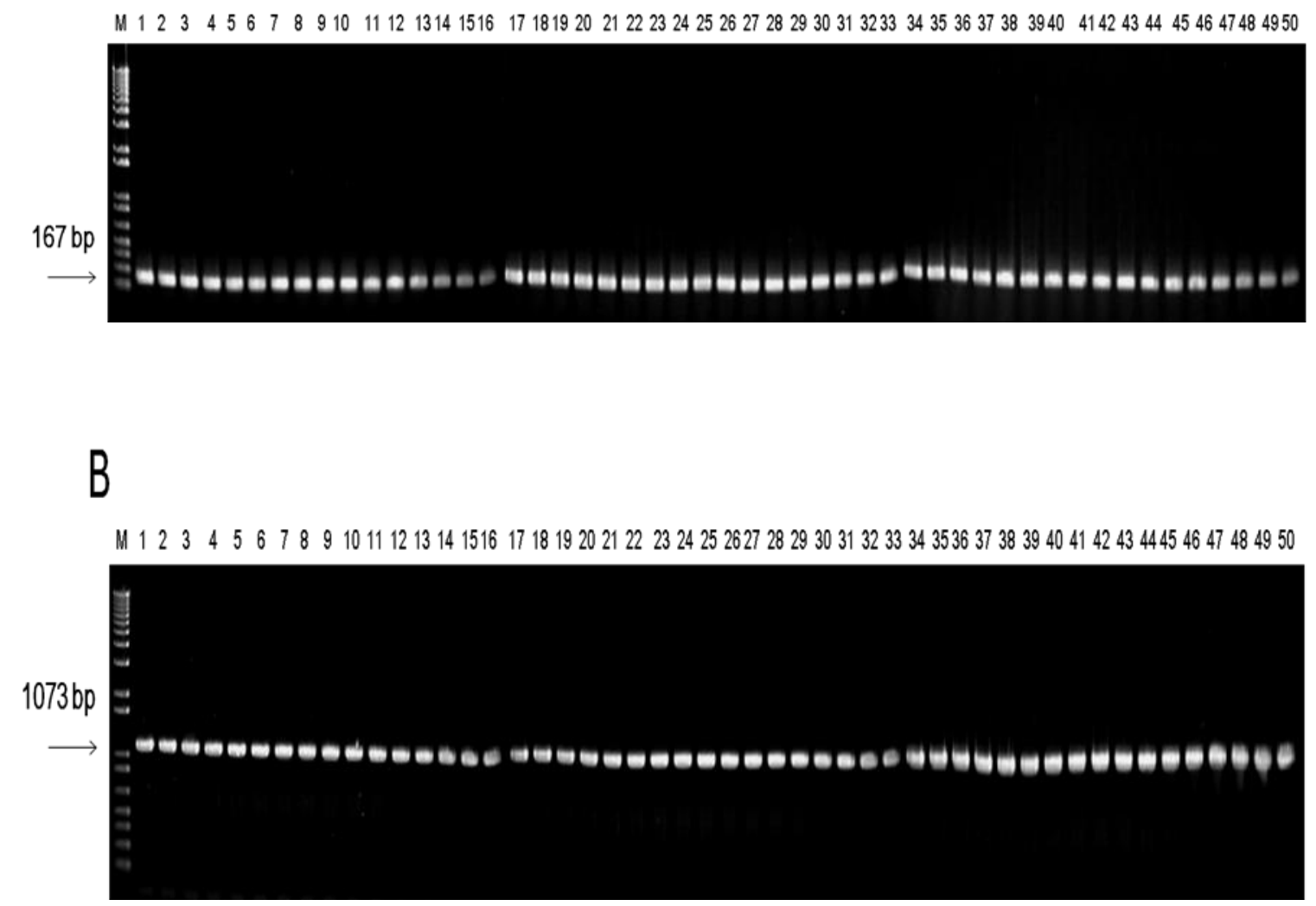

Figure 1. Agarose gel electrophoresis of $\mathrm{V} 6$ and $\mathrm{V} 1$ to $\mathrm{V} 6$ regions of $16 S-r R N A$ gene amplicons. A: universal primers amplifying V6 region; B: universal primers amplifying V1 to V6 region. Lane $\mathrm{M}$ is $1 \mathrm{~Kb}$ DNA Ladder, lanes 1 to 20 are Pseudomonas isolates, lanes 21 to 35 are Escherichia isolates and lanes 36 to 50 are Klebsiella isolates.

results of the 20 tested Pseudomonas isolates; 15 isolates of Ps. aeruginosa, 2 isolates of Ps. putida and 3 isolates of Ps. fluorescens.

\section{Escherichia}

All Escherichia confirmed as E. coli by the molecular approach except Escherichia isolates No. 10 and 11, their sequencing results showed that these isolates were mixed samples with a majority of $E$. coli and a minority of Klebsiella without species Id.

All $E$. coli identified using sequencing of $\mathrm{V} 6$ region of $16 S-r R N A$ gene confirmed as $E$. coli by sequencing of $V 1$ to $\mathrm{V} 6$ region of $16 S-r R N A$ gene, moreover sequencing of V1 to V6 region of $16 S-r R N A$ could discover the species Id of the two Klebsiella species which were mixed with $E$. coli in the isolates No.10 and 11 and identified as $K$. pneumonia.

\section{Klebsiella}

Regarding the Klebsiella isolates, out of the 15 tested isolates, 11 isolates were identified as Unknown Enterobacterial Bacterium and 4 Klebsiella isolates without species Id.

The sequencing of $\mathrm{V} 1$ to $\mathrm{V} 6$ region of $16 S-r R N A$ gene could discover the species Id of Klebsiella isolates. Out of the 15 tested isolates, the 11 isolates that were identified as Unknown Enterobacterial Bacterium using sequencing of $\mathrm{V} 6$ region of $16 S-r R N A$ gene was confirmed as $K$. pneumonia using sequencing of $\mathrm{V} 1$ to $\mathrm{V} 6$ region of 16S-rRNA gene. Interestingly, the 4 Klebsiella isolates without species Id were classified as 2 isolates of $K$. oxytoca and 2 Klebsiella isolates gave a close hit of $96.2 \%$ to Klebsiella species in the gene bank without species Id.

\section{Comparison between 16S-rRNA V6 region sequencing and 16S-rRNA V1 to V6 region}

\section{sequencing methods of identification}

The comparison is shown in Tables 2 and 3. Our results showed that, sequence analysis of conserved "house keeping" genes such as the bacterial 16S-rRNA gene are increasingly being used to identify bacterial species in clinical practice and scientific investigations. In the case of $16 S-r R N A$ analysis, species identification is easiest when 
Table 2. V6 region versus $\mathrm{V} 1$ to $\mathrm{V} 6$ region sequencing identification of Pseudomonas isolates.

\begin{tabular}{|c|c|c|c|c|c|c|c|}
\hline $\begin{array}{l}\text { Strain } \\
\text { ID }\end{array}$ & $\begin{array}{l}\text { 16S-rRNA V6 } \\
\text { region } \\
\text { sequence Id }\end{array}$ & $\begin{array}{l}\text { 16S-rRNA V1 to } \\
\text { V6 region } \\
\text { sequence Id }\end{array}$ & $\begin{array}{l}\text { Geographical } \\
\text { Source }\end{array}$ & $\begin{array}{l}\text { Strain } \\
\text { ID }\end{array}$ & $\begin{array}{l}\text { 16S-rRNA V6 } \\
\text { region } \\
\text { sequence Id }\end{array}$ & $\begin{array}{l}\text { 16S-rRNA V1 to } \\
\text { V6 region } \\
\text { sequence Id }\end{array}$ & $\begin{array}{l}\text { Geographica } \\
\text { Source }\end{array}$ \\
\hline 1 & $\begin{array}{c}\text { Pseudomonas } \\
\text { aeruginosa }\end{array}$ & $\begin{array}{c}\text { Pseudomonas } \\
\text { aeruginosa }\end{array}$ & (UNC) & 11 & $\begin{array}{c}\text { Pseudomonas } \\
\text { Spp. }\end{array}$ & $\begin{array}{l}\text { Pseudomonas } \\
\text { fluorescens }\end{array}$ & $(\mathrm{MUH})$ \\
\hline 2 & $\begin{array}{c}\text { Pseudomonas } \\
\text { aeruginosa }\end{array}$ & $\begin{array}{c}\text { Pseudomonas } \\
\text { aeruginosa }\end{array}$ & $(\mathrm{MUH})$ & 12 & $\begin{array}{c}\text { Pseudomonas } \\
\text { aeruginosa }\end{array}$ & $\begin{array}{c}\text { Pseudomonas } \\
\text { aeruginosa }\end{array}$ & (UNC) \\
\hline 3 & $\begin{array}{c}\text { Pseudomonas } \\
\text { aeruginosa }\end{array}$ & $\begin{array}{c}\text { Pseudomonas } \\
\text { aeruginosa }\end{array}$ & (UNC) & 13 & $\begin{array}{c}\text { Pseudomonas } \\
\text { aeruginosa }\end{array}$ & $\begin{array}{c}\text { Pseudomonas } \\
\text { aeruginosa }\end{array}$ & (UNC) \\
\hline 4 & $\begin{array}{l}\text { Pseudomonas } \\
\text { putida }\end{array}$ & $\begin{array}{l}\text { Pseudomonas } \\
\text { putida }\end{array}$ & $(\mathrm{MUH})$ & 14 & $\begin{array}{c}\text { Pseudomonas } \\
\text { aeruginosa }\end{array}$ & $\begin{array}{c}\text { Pseudomonas } \\
\text { aeruginosa }\end{array}$ & $(\mathrm{MUH})$ \\
\hline 5 & $\begin{array}{c}\text { Pseudomonas } \\
\text { aeruginosa }\end{array}$ & $\begin{array}{c}\text { Pseudomonas } \\
\text { aeruginosa }\end{array}$ & $(\mathrm{MUH})$ & 15 & $\begin{array}{c}\text { Pseudomonas } \\
\text { aeruginosa }\end{array}$ & $\begin{array}{c}\text { Pseudomonas } \\
\text { aeruginosa }\end{array}$ & (PUH) \\
\hline 6 & $\begin{array}{c}\text { Pseudomonas } \\
\text { Spp. }\end{array}$ & $\begin{array}{l}\text { Pseudomonas } \\
\text { fluorescens }\end{array}$ & $(\mathrm{MUH})$ & 16 & $\begin{array}{c}\text { Pseudomonas } \\
\text { aeruginosa }\end{array}$ & $\begin{array}{c}\text { Pseudomonas } \\
\text { aeruginosa }\end{array}$ & (PUH) \\
\hline 7 & $\begin{array}{c}\text { Pseudomonas } \\
\text { aeruginosa }\end{array}$ & $\begin{array}{c}\text { Pseudomonas } \\
\text { aeruginosa }\end{array}$ & (PUH) & 17 & $\begin{array}{l}\text { Pseudomonas } \\
\text { putida }\end{array}$ & $\begin{array}{l}\text { Pseudomonas } \\
\text { putida }\end{array}$ & (PUH) \\
\hline 8 & $\begin{array}{c}\text { Pseudomonas } \\
\text { aeruginosa }\end{array}$ & $\begin{array}{c}\text { Pseudomonas } \\
\text { aeruginosa }\end{array}$ & (PUH) & 18 & $\begin{array}{c}\text { Pseudomonas } \\
\text { aeruginosa }\end{array}$ & $\begin{array}{c}\text { Pseudomonas } \\
\text { aeruginosa }\end{array}$ & (PUH) \\
\hline 9 & $\begin{array}{c}\text { Pseudomonas } \\
\text { aeruginosa }\end{array}$ & $\begin{array}{c}\text { Pseudomonas } \\
\text { aeruginosa }\end{array}$ & (PUH) & 19 & $\begin{array}{c}\text { Pseudomonas } \\
\text { aeruginosa }\end{array}$ & $\begin{array}{c}\text { Pseudomonas } \\
\text { aeruginosa }\end{array}$ & (PUH) \\
\hline 10 & $\begin{array}{c}\text { Pseudomonas } \\
\text { Spp. }\end{array}$ & $\begin{array}{l}\text { Pseudomonas } \\
\text { fluorescens }\end{array}$ & $(\mathrm{MUH})$ & 20 & $\begin{array}{c}\text { Pseudomonas } \\
\text { aeruginosa }\end{array}$ & $\begin{array}{c}\text { Pseudomonas } \\
\text { aeruginosa }\end{array}$ & (UNC) \\
\hline
\end{tabular}

Urology and Nephrology Center (UNC), Mansoura University Hospital (MUH), Pediatric University Hospital (PUH).

most or the entire gene can be sequenced. However, DNA sequencing is impractical in medical diagnostics where speed is often of the essence. Species-specific sequences can be identified very rapidly in assays that combine nucleic acid amplification and a sequencespecific probe of the amplified product. These approaches are usually only able to query short DNA sequences; therefore, it is important to identify the regions within the target gene that supply the most taxonomic information in the smallest stretch of nucleotides. Additional benefits of small amplicon size may include increased assay sensitivity and applicability to archival specimens.

Since The hyper-variable 167 nucleotides-long V6 region (907-1073) is the shortest hyper-variable region with the maximum degree of sequence heterogeneity (Chakravorty et al., 2007), so the sequences obtained in this study may be added to the existing sequences in the gene bank to facilitate the identification process especially in the case of Klebsiella isolates and Pseudomonas fluorescens isolates.

Interestingly our results put the light on the power of 16S-rRNA sequence analysis to identify novel pathogens and indicate the criteria for identification using 16S-rRNA sequence analysis where, identification to the species level was defined as a $16 S-r R N A$ sequence similarity of more than or equal to $99 \%$ with that of the prototype strain sequence in the gene bank; identification to the genus level was defined as a $16 S-r R N A$ sequence similarity of more than or equal $97 \%$ with that of the prototype strain sequence in the gene bank. A failure to identify was defined as a $16 S-r R N A$ sequence similarity score of lower than $97 \%$ with those deposited in the gene bank at the time of analysis (Drancourt et al., 2000). Therefore it's suggested that the two Klebsiella strains No. 9 and 12 lacking species Id are two novel Klebsiella species as they are $96.2 \%$ similar to Klebsiella species in the gene bank and this is in accordance with the study of Petti (2007), who stated that 16S-rRNA gene sequence data on an individual strain with a nearest neighbor exhibiting a similarity score of lower than $97 \%$ represents a new species.

The obtained identification results of Escherichia samples No. 10 and 11 show the ability of 16S-rRNA sequence data analysis for diagnosis of mixed samples with major and minor or fastidious non-cultivable microorganisms as the sequencing chromatograms will show mixed signals and this is in accordance with study conducted by Rantakokko et al. (2000), who reported that, although conventional culture methods of identification detected Staphylococcus only in pus clinical sample, further 16S-rRNA analysis suggested the presence of other bacterial species in addition to Staphylococci. On the other hand, other studies showed that mixed cultures led to $1 \%$ of $16 S-r R N A$ based identification failures, either because the wrong colony was selected on subculture or because more than one bacterial species was inadvertently included in the amplification, resulting in ambiguous 16S-rRNA data. These studies recommend 
Table 3. V6 region versus V1 to V6 region sequencing identification of Escherichia and Klebsiella isolates.

\begin{tabular}{|c|c|c|c|c|c|c|c|}
\hline $\begin{array}{l}\text { Strain } \\
\text { ID }\end{array}$ & $\begin{array}{l}16 S-r R N A \quad \text { V6 } \\
\text { region } \\
\text { sequence Id }\end{array}$ & $\begin{array}{l}\text { 16S-rRNA V1 to } \\
\text { V6 region } \\
\text { sequence Id }\end{array}$ & $\begin{array}{l}\text { Geographical } \\
\text { Source }\end{array}$ & $\begin{array}{l}\text { Strain } \\
\text { ID }\end{array}$ & $\begin{array}{l}\text { 16S-rRNA V6 } \\
\text { region sequence } \\
\text { Id }\end{array}$ & $\begin{array}{l}\text { 16S-rRNA V1 to } \\
\text { V6 region } \\
\text { sequence Id }\end{array}$ & $\begin{array}{l}\text { Geographical } \\
\text { Source }\end{array}$ \\
\hline 4 & Escherichia coli & Escherichia coli & $(\mathrm{MUH})$ & 1 & $\begin{array}{l}\text { Unknown } \\
\text { Enterobacterial } \\
\text { Bacterium }\end{array}$ & $\begin{array}{l}\text { Klebsiella } \\
\text { pneumoniae }\end{array}$ & (UNC) \\
\hline 6 & Escherichia coli & Escherichia coli & $(\mathrm{MUH})$ & 3 & $\begin{array}{l}\text { Unknown } \\
\text { Enterobacterial } \\
\text { Bacterium }\end{array}$ & $\begin{array}{l}\text { Klebsiella } \\
\text { pneumoniae }\end{array}$ & (UNC) \\
\hline 8 & Escherichia coli & Escherichia coli & $(\mathrm{MUH})$ & 4 & $\begin{array}{l}\text { Unknown } \\
\text { Enterobacterial } \\
\text { Bacterium }\end{array}$ & $\begin{array}{l}\text { Klebsiella } \\
\text { pneumoniae }\end{array}$ & (UNC) \\
\hline 9 & Escherichia coli & Escherichia coli & $(\mathrm{MUH})$ & 5 & $\begin{array}{l}\text { Unknown } \\
\text { Enterobacterial } \\
\text { Bacterium }\end{array}$ & $\begin{array}{l}\text { Klebsiella } \\
\text { pneumoniae }\end{array}$ & (UNC) \\
\hline 10 & $\begin{array}{l}\text { E.coli } \\
\text { Klebsiella spp. }\end{array}$ & $\begin{array}{l}\text { E.coli Klebsiella } \\
\text { pneumoniae }\end{array}$ & $(\mathrm{MUH})$ & 6 & Klebsiella spp. & $\begin{array}{l}\text { Klebsiella } \\
\text { oxytoca }\end{array}$ & (UNC) \\
\hline 11 & $\begin{array}{l}\text { E.coli } \\
\text { Klebsiella spp. }\end{array}$ & $\begin{array}{l}\text { E.coli Klebsiella } \\
\text { pneumoniae }\end{array}$ & $(\mathrm{MUH})$ & 7 & $\begin{array}{l}\text { Unknown } \\
\text { Enterobacterial } \\
\text { Bacterium }\end{array}$ & $\begin{array}{l}\text { Klebsiella } \\
\text { pneumoniae }\end{array}$ & (UNC) \\
\hline 12 & Escherichia coli & Escherichia coli & $(\mathrm{MUH})$ & 8 & $\begin{array}{l}\text { Unknown } \\
\text { Enterobacterial } \\
\text { Bacterium }\end{array}$ & $\begin{array}{l}\text { Klebsiella } \\
\text { pneumoniae }\end{array}$ & (UNC) \\
\hline 14 & Escherichia coli & Escherichia coli & (PUH) & 9 & Klebsiella spp. & Klebsiella spp. & (UNC) \\
\hline 15 & Escherichia coli & Escherichia coli & $(\mathrm{MUH})$ & 10 & $\begin{array}{l}\text { Unknown } \\
\text { Enterobacterial } \\
\text { Bacterium }\end{array}$ & $\begin{array}{l}\text { Klebsiella } \\
\text { pneumoniae }\end{array}$ & (UNC) \\
\hline 16 & Escherichia coli & Escherichia coli & $(\mathrm{MUH})$ & 11 & $\begin{array}{l}\text { Unknown } \\
\text { Enterobacterial } \\
\text { Bacterium }\end{array}$ & $\begin{array}{l}\text { Klebsiella } \\
\text { pneumoniae }\end{array}$ & (PUH) \\
\hline 17 & Escherichia coli & Escherichia coli & $(\mathrm{MUH})$ & 12 & Klebsiella spp. & Klebsiella spp. & (PUH) \\
\hline 21 & Escherichia coli & Escherichia coli & $(\mathrm{MUH})$ & 14 & Klebsiella spp. & $\begin{array}{l}\text { Klebsiella } \\
\text { oxytoca }\end{array}$ & (PUH) \\
\hline 22 & Escherichia coli & Escherichia coli & (PUH) & 15 & $\begin{array}{l}\text { Unknown } \\
\text { Enterobacterial } \\
\text { Bacterium }\end{array}$ & $\begin{array}{l}\text { Klebsiella } \\
\text { pneumoniae }\end{array}$ & (UNC) \\
\hline 23 & Escherichia coli & Escherichia coli & (PUH) & 16 & $\begin{array}{l}\text { Unknown } \\
\text { Enterobacterial } \\
\text { Bacterium }\end{array}$ & $\begin{array}{l}\text { Klebsiella } \\
\text { pneumoniae }\end{array}$ & (UNC) \\
\hline 24 & Escherichia coli & Escherichia coli & $(\mathrm{PUH})$ & 17 & $\begin{array}{l}\text { Unknown } \\
\text { Enterobacterial } \\
\text { Bacterium }\end{array}$ & $\begin{array}{l}\text { Klebsiella } \\
\text { pneumoniae }\end{array}$ & (UNC) \\
\hline
\end{tabular}

Urology and Nephrology Center (UNC), Mansoura University Hospital (MUH), Pediatric University Hospital (PUH).

that more attention should therefore be paid to achieving a pure culture prior to $16 S$-rRNA-based identification (Drancourt et al., 2000). Alternatively, mixed 16S-rRNA sequences could be separated by, for example, denaturing gradient gel electrophoresis prior to sequencing for more accurate identification (Teske et al., 1996).

Moving forward with the sequencing results, in this study, we could use the phylogeny to determine the relatedness between different isolates and the source of isolation Figure 2.

From the phylogenetic trees, it is clear that both Pseudomonas and Escherichia species were shared the intra-species genetic distance between individual isolates of 0.005 . On the other hand, the intra-species genetic distance between individual isolates of the Klebsiella species was higher up to 0.01 . These findings can show the high rate of evolution and the genetic variation in Klebsiella species compared to Pseudomonas and Escherichia species.

In conclusion, our results showed that identifying bacteria isolated in the clinical laboratory by DNA sequencing techniques can improve clinical microbiology by better identifying poorly described, rarely isolated, or biochemically aberrant strains. 16S-rRNA gene sequences allow bacterial 

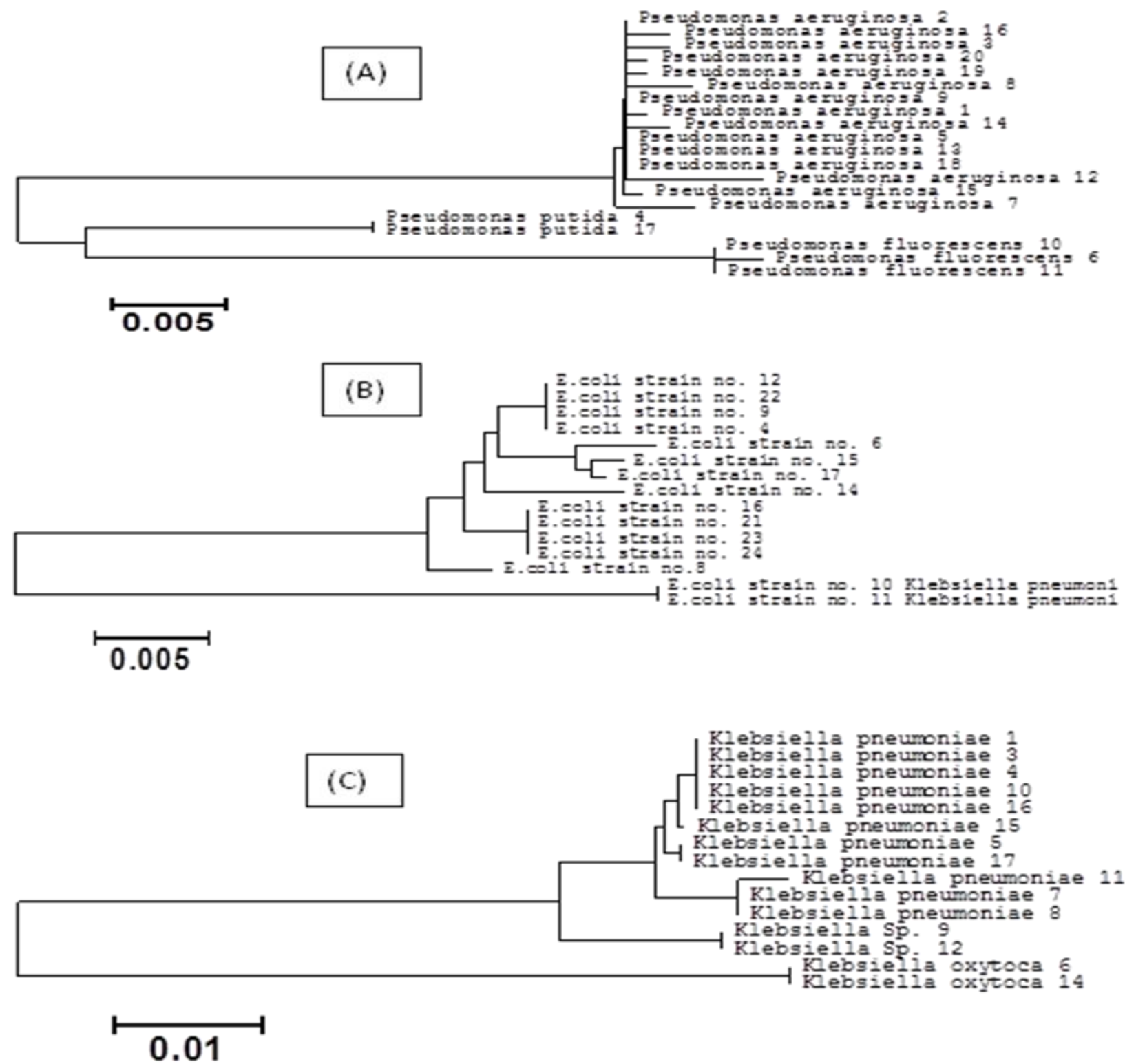

Figure 2. Phylogenetic neighbor joining trees $\mathrm{A}, \mathrm{B}$ and $\mathrm{C}$ of $16 S \mathrm{rRNA}$ amplified from tested isolates of Pseudomonas, Escherichia and Klebsiella species respectively.

identification that is more robust, reproducible, and accurate than that obtained by phenotypic testing. The test results are less subjective. Sequence analysis of 16S-rRNA gene can lead to the discovery of novel pathogens, the identification of non-cultured bacteria and allowing independence from growth conditions. In addition our results can enrich the gene bank by the newly obtained V6 region sequences in the present study to facilitate the identification process.

Moreover, the DNA sequencing technologies have been evolved in the last 20 years from the dye termination to Pyrosequencing ending by single molecule sequencing. The race of different sequencing technologies will grantee high accuracy and low cost to be efficient and suitable for medium and small microbiological laboratories.

\section{Authors' contributions}

$E A, H R, S S$ and EW participated in the study design. EA, BR participated in sample collection and did the microbiological work. EA and SS did the molecular work. EA and SS participated in data analysis and wrote the manuscript. All authors read and approved the final manuscript.

\section{REFERENCES}

Baker GC, Smith JJ, Cowan DA (2003). Review and re-analysis of 
domain-specific $16 \mathrm{~S}$ primers. J. Microbiol. Methods 55:541-555.

Barrow GI, Feltham RK (1993). Cowan and Steel's Manual for the identification of Medical Bacteria $3^{\text {rd }}$ Ed., University press, Cambridge, U.K. 136-38.

Beighton D, Hardie JM, Whiley RA (1991). A scheme for the identification of viridians streptococci. J. Med. Microbiol. 35:367-372.

Boettger EC (1996). Approaches for identification of microorganisms. ASM News 62:247-250.

Bosshard PP, Abels S, Altwegg M, Bottger EC, Zbinden R (2004). Comparison of Conventional and Molecular Methods for Identification of Aerobic Catalase-Negative Gram-Positive Cocci in the Clinical Laboratory. J. Clin. Microbiol. 42:2065-2073.

Chakravorty S, Helb D, Burday M, Connell N, Alland D (2007). A detailed analysis of $16 \mathrm{~S}$ ribosomal RNA gene segments for the diagnosis of pathogenic bacteria. J. Microbiol. Methods. 69:330-339.

Clarridge III JE (2004). Impact of 16S-rRNA gene sequence analysis for identification of bacteria on clinical microbiology and infectious diseases. Clin. Microbiol. Rev. 17:840-862.

College JG, Miles RS, Watt B (1996). Tests for the identification of bacteria. In: Mackie and Mccartney. Practical Medical Microbiology, $14^{\text {th }}$ Edn., Vol., I, pp. 413-424. Churchill Livingstone, N.Y, U.S.A.

Drancourt M, Bollet C, Carlioz A, Martelin R, Gayral JP, Raoult D (2000). 16S Ribosomal DNA Sequence Analysis of a Large Collection of Environmental and Clinical Unidentifiable Bacterial Isolates. J. Clin Microbiol. 38:3623-3630.

Govan JRW (1996). Pseudomonas aeruginosa, Stenotrophomonas, Burkholderia. In collee, A.G. Marmion, B.P. and Simmons, A. (Eds): Mackie and Mccartney Practical Medical microbiology. Churchill Livingstone, New York, $14^{\text {th }}$ Edn, Vo. I, PP: 413-424.

Kim M, Morrison M, Yu ZT (2011) Evaluation of different partial 16S rRNA gene sequence regions for phylogenetic analysis of microbiomes. J. Microbiol. Methods 84:81-87.

Kirschner P, Springer B, Vogel U, Meier A, Wrede A, Kiekenbeck M, Bange FC, Bottger EC (1993). Genotypic identification of mycobacteria by nucleic acid sequence determination: report of a 2-year experience in a clinical laboratory. J. Clin. Microbiol. 31:2882-2889.

Maurin M, Roux V, Stein A, Ferrier F, Viraben R, Raoult D. (1994). Isolation and characterization by immunofluorescence, sodium dodecyl sulfate- polyacrylamide gel electrophoresis, Western blot, restriction fragment length polymorphism-PCR, 16S-rRNA gene sequencing, and pulsed-field gel electrophoresis of Rochalimaea quintana from a patient with bacillary angiomatosis. J. Clin. Microbiol. 32:1166-1171.

Munson MA, Banerjee A, Watson TF, Wade WG (2004). Molecular analysis of the microflora associated with dental caries. J. Clin. Microbiol. 42:3023-3029.

Patel JB (2001). 16S-rRNA gene sequencing for bacterial pathogen identification in the clinical laboratory. Mol. Diagn. 6:313-321.
Petti CA (2007). Detection and identification of microorganisms by gene amplification and sequencing. Clin. Infect. Dis. 44:1108-1114.

Poyart C, Quesne G, Coulon S, Berche P, Trieu-Cuot P (1998). Identification of streptococci to species level by sequencing the gene encoding the manganese-dependent superoxide dismutase. J. Clin. Microbiol. 36:41-47.

Rantakokko JK, Nikkari S, Jalava J, Eerola E, Skurnik M, Meurman O, Ruuskanen O, Alanen A, Kotilainen E, Toivanen P, Kotilainen P (2000). Direct amplification of rRNA genes in diagnosis of bacterial infections. J. Clin. Microbiol. 38:32-39.

Sanger F, Nicklen S, Coulson AR (1977). DNA sequencing with chain-terminating inhibitors. Proc. Natl. Acad. Sci. 74:5463-5467.

Sundquist A, Bigdeli S, Jalili R, Druzin M, Waller S, Pullen K, El-Sayed Y, Taslimi M, Batzoglou S, Ronaghi M (2007). Bacterial flora-typing with targeted, chip-based Pyrosequencing. BMC Microbiol. 7:108.

Tang YW, Ellis NM, Hopkins MK, Smith DH, Dodge DE, Persing DH (1998). Comparison of phenotypic and genotypic techniques for identification of unusual aerobic pathogenic gram-negative bacilli. J. Clin. Microbiol. 36:3674-3679.

Tang YW, Ellis NM, Hopkins MK, Smith DH, Dodge DE, Persing DH (1998). Comparison of phenotypic and genotypic techniques for identification of unusual aerobic pathogenic gram-negative bacilli. J. Clin. Microbiol. 36:3674-3679.

Tardif G, Sulavik MC, Jones GW, Clewell DB (1989). Spontaneous switching of the sucrose-promoted colony phenotype in Streptococcus sanguis. Infect. Immun. 57:3945-3948.

Teske A, Sigalevich P, Cohen Y, Muyzer G (1996). Molecular identification of bacteria from a co-culture by denaturing gradient gel electrophoresis of $16 \mathrm{~S}$ ribosomal DNA fragments as a tool for isolation in pure culture. Appl. Environ. Microbiol. 62:4210-4215.

Trotha R, Hanck T, Konig W, Konig B (2001). Rapid ribosequencing an effective diagnostic tool for detecting microbial infection. Infection 29:12-16.

Van de Peer Y, Chapelle S, De Wachter R (1996). A quantitative map of nucleotide substitution rates in bacterial rRNA. Nucleic. Acids Res. 24:3381-3391.

Wilson KH, Blitchington RB, Greene RC (1990). Amplification of bacterial $16 \mathrm{~S}$ ribosomal DNA with polymerase chain reaction. J. Clin. Microbiol. 28:1942-1946.

Woese CR, Fox GE (1977). Phylogenetic structure of the prokaryotic domain: the primary kingdoms. Proc. Natl. Acad. Sci. USA 74:5088-5090.

Woese CR, Kandler O, Wheelis ML (1990). Towards a natural system of organisms: proposal for the domains Archaea, Bacteria, and Eucarya. Proc. Natl. Acad. Sci. USA 87:4576-4579. 